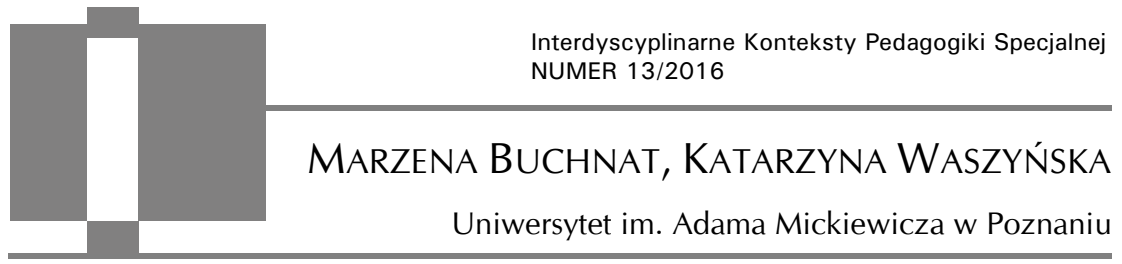

\title{
Oczekiwania rodziców wobec edukacji seksualnej dzieci i młodzieży z lekką niepełnosprawnością intelektualną
}

\begin{abstract}
Marzena Buchnat, Katarzyna Waszyńska, Oczekiwania rodziców wobec edukacji seksualnej dzieci i młodzieży z lekkq niepetnosprawnościa intelektualna [Parents' expectations from sexual education of children and adolescents with with mild intellectual disability]. Interdyscyplinarne Konteksty Pedagogiki Specjalnej, nr 13, Poznań 2016. Pp. 103-123. Adam Mickiewicz University Press. ISSN 2300-391X
\end{abstract}

The role of parents in supporting the children's psychosexual development is extremely significant. It is them who introduce first in the system of values, rules, behavioral standards, they teach how to express feelings and emotions and this is why the family home is the best place to start sexual education. It is very difficult for many parents to transfer knowledge about sexuality to children, especially for the parents of children with mental disability. They present different attitudes towards the children's sexuality, which imply how they lead the education on this topic. Conducted research aimed at exploring the parents' opinions on sexual education at home. Research results showed a range of difficulties (among others insufficient preparation or knowledge) concerning the conversations with children about their psychosexual development. It is necessary to support the parents with knowledge, information as well as with competences and skills in sexual education of children.

KEY WORDS: sexual education, psychosexual development of children with slight mental disability 
Przekazywanie wiedzy dzieciom na temat seksualności jest trudne dla wielu rodziców. Często nie wiedzą, kiedy mogą rozpoczać takie rozmowy, jaki ma być zakres ich treści, a także czy i w jakim stopniu odpowiadać na pytania swoich dzieci. Przeważnie wynika to $\mathrm{z}$ faktu, iż sami $\mathrm{w}$ okresie dzieciństwa i dojrzewania nie rozmawiali na tematy związane $\mathrm{z}$ seksualnością ze swoimi rodzicami, a także z obaw, aby przedwczesnymi informacjami nie spowodować zwiększonego zainteresowania tą sferą życia. Kiedy już dochodzi do tego typu rozmów, rodzice wskazują na problemy wynikające $z$ braku wiedzy, nieznajomości poprawnego słownictwa, a także trudnych emocji towarzyszących tym rozmowom: wstydu i zażenowania ${ }^{1}$.

W sposób szczególny może to dotyczyć rodziców dzieci z niepełnosprawnością intelektualną, którzy na swojej drodze wychowawczej napotykają znacznie więcej trudności wynikających ze specjalnych potrzeb swoich podopiecznych.

Sytuacja rodziców wychowujących dziecko z lekką niepełnosprawnością intelektualną jest bardzo złożona i w dużej mierze implikowana faktem akceptacji niepełnosprawności swojego dziecka. W wynikach przeprowadzonych badań ujawnia się zależność, która wskazuje na daleko idące konsekwencje dla rodziny, w której pojawia się dziecko z niepełnosprawnością intelektualną². Do czynników, które warunkują sposób przyjęcia przez rodziców informacji o niepełnosprawności dziecka, należą: etap rozwoju, na którym po-

${ }^{1}$ G. Pighin, Skąd się bierze dziecko w brzuchu mamy?, Oficyna Wydawnicza GMP, Poznań, 1995; D.W. Haffner, Jak rozmawiać z dziećmi o sprawach intymnych?, Grupa Wydawnicza Bertelsmann Media, Warszawa 2002; F. Saint-Pierre, M.F. Viau, Seksualność dziecka, Bauer - Weltbild Media Sp. z. o.o, Warszawa 2006; CBOS, 2010, K. Waszyńska, Przejawy seksualności dziecka w wieku przedszkolnym - kontekst edukacyjny, [w:] Przemiany seksualności w społeczeństwie wspótczesnym. Teoria i rzeczywistość, red. Z. Lew-Starowicz, K. Waszyńska, Wydawnictwo Naukowe UAM, Poznań 2012.

${ }^{2}$ H. Borzyszkowska, Dziecko upośledzone w rodzinie, [w:] Pedagogika rewalidacyjna, red. A. Hulek, PWN Warszawa 1998; W. Dykcik, Pedagogika specjalna, Wydawnictwo Naukowe UAM, Poznań 2006; E. Minczakiewicz, Dziecko niepetnosprawne w rodzinie i w szkole, Kraków 2002; A. Twardowski, Sytuacja rodzin dzieci niepetnosprawnych, [w:] Dziecko niepetnosprawne w rodzinie, red. I. Obuchowska, WSiP, Warszawa 2005. 
jawiła się niepełnosprawność, sposób w jaki rodzice dowiadują się o niepełnosprawności, rodzaj i stopień niepełnosprawności, stopień widoczności niepełnosprawności, błędy przy informowaniu rodziców, zachowanie dziecka, preferowane przez rodziców wartości i cele życiowe. Czynniki te wpływają na czas trwania kryzysów emocjonalnych rodziców po uzyskaniu informacji o niepełnosprawności dziecka, które można podzielić na następujące okresy: szoku, kryzysu emocjonalnego, pozornego przystosowania i konstruktywnego przystosowania ${ }^{3}$. Droga rodziców do zaakceptowania niepełnosprawności intelektualnej swojego dziecka prowadzi przez szereg bardzo trudnych faz. Nie wszystkim rodzicom udaje się przez nie przejść i dojść do pogodzenia się z obiektywnymi możliwościami rozwojowymi swoich podopiecznych. Rodzice wobec dzieci z niepełnosprawnością intelektualną, oprócz akceptacji, prezentują równiż postawy: nadmiernej opieki, nadmiernego obciążenia i odtrącenia 4 . To właśnie one będą miały znaczenie dla podejmowanych działań na rzecz uspołeczniania oraz wspierania autonomii i niezależności swoich dzieci. Rodzice, jak zauważa Zbigniew Izdebski ${ }^{5}$, odgrywają znaczącą i wyjątkową rolę w rozwoju społecznoseksualnym dzieci z niepełnosprawnością intelektualną, głównie przez postawy, które sami w tej sferze prezentują. Przykład idący ze strony dorosłych, wyrażany werbalnie i niewerbalnie, stanowi podstawę, na której dzieci te budują swoje doświadczenia.

Przekazywanie wiedzy na temat seksualności, jak już zostało wspomniane, jest trudne dla wielu rodziców. Jednak w omawianej sytuacji jest związane $\mathrm{z}$ dodatkowym napięciem wynikającym

${ }^{3}$ A. Twardowski, Sytuacja rodzin dzieci niepetnosprawnych, [w:] Dziecko niepetnosprawne w rodzinie, red. I. Obuchowska, WSiP, Warszawa 2005, s. 21-31; J. Laush-Żuk, Pedagogika osób z umiarkowanym, znacznym i głębokim upośledzeniem umysłowym, [w:] Pedagogika specjalna, red. W. Dykcik, Wydawnictwo Naukowe UAM, Poznań 2001, s. 153-155.

${ }^{4}$ Mary D. Sheridan za: K. Boczar, Młodzież upośledzona umystowo w rodzinie i środowisku pracy, Warszawa 1982.

${ }^{5}$ Z. Izdebski, Rodzice dziecka niepetnosprawnego intelektualnie wobec jego seksualności, [w:] O seksualności osób niepetnosprawnych, red. A. Ostrowska, IRSS, Warszawa 2007. 
z możliwości intelektualnych dzieci. Rodzice małoletnich z lekką niepełnosprawnością intelektualną, którzy się z nią nie pogodzili, często ją wypierają, a co za tym idzie, nie widzą potrzeby przekazania wiedzy $w$ tym obszarze $w$ specjalnie dostosowany sposób lub tak są skoncentrowani na niepełnosprawności dziecka, że świadomie lub nie, nie pomagają podopiecznym $\mathrm{w}$ rozwoju tożsamości płciowej ${ }^{6}$. Druga grupa rodziców zauważająca taką potrzebę, podejmuje próby rozmowy na ten temat, ale często nie wie, jak tę wiedzę przekazać w odpowiedni sposób. Boją się, żeby podejmowana tematyka seksualności nie spowodowała rozbudzenia $w$ tym obszarze. Część rodziców nie zauważa lub nie chce zauważać faktu, iż ich dziecko staje się osobą dorosłą. Wynika to $\mathrm{z}$ jednej strony z przeświadczenia, że tylko w dzieciństwie osoby z niepełnosprawnością intelektualną mogą osiągać postęp, więc wyparcie dorosłości swojego dziecka gwarantuje możliwość dalszego rozwoju, z drugiej strony ograniczone możliwości intelektualne pozwalają na traktowanie ich jak "dużych dzieci"7. Rodzice przez to uciekają od tego tematu, licząc, że problemy z nim związane nigdy nie wystąpią. Taka ambiwalentna postawa wobec seksualności u osób z lekką niepełnosprawnością intelektualną może kształtować negatywny stosunek do własnej seksualności, budzić poczucie bezradności lub winy.

Rodzice prezentują zróżnicowane postawy wobec seksualności swoich dzieci. Można za Mikołajem Kozakiewiczem ${ }^{8}$ wyodrębnić następujące ich grupy:

1) rygorystycznych i tradycjonalistycznych - niedopuszczających do rozmów dotyczących seksualności, karzących za jej przejawy;

${ }^{6}$ M. Kościelska, Niechciana seksualność: o ludzkich potrzebach osób niepetnosprawnych intelektualnie, Jacek Senatorski \& Co, Warszawa 2004.

7 Ż. Stelter, Dorastanie osób z niepetnosprawnościq intelektualna, Warszawa 2009, s. 112-113.

${ }^{8}$ M. Kozakiewicz, U podstaw wychowania seksualnego, PZWL, Warszawa 1969, s. 296-298. 
2) liberalnych i postępowych - traktujących potrzeby seksualne jako normalne potrzeby fizjologiczne, szybko wprowadzający do domu edukację seksualną;

3) zdezorientowanych i bezradnych - pragnących dobrze wychować swoje dzieci, jednak brakuje im odwagi, wiedzy, elokwencji do podjęcia edukacji seksualnej, dlatego oddają ją w ręce szkoły;

4) pasywnych wychowawczo - niezajmujących się wychowaniem, przekazywaniem wzorców;

5) świadomie wychowujących seksualnie - przywiązujących wagę nie tylko do edukacji seksualnej, ale też do jej jakości.

W literaturze możemy spotkać inne późniejsze podziały np. Marly R. Brassard, Roberta Germaina i Stuarta N. Harta9', którzy wyróżnili następujące typy środowisk rodzinnych ze względu na edukację seksualną: idealne, wystarczająco dobre, nieuchwytne, przyzwalające, negatywistyczne, uwodzące i jawnie seksualizujące. Maria Beisert 10 wyodrębniła zaś następujące typy środowiska rodzinnego: akceptujący, niezaburzający, próżni, nadmiernie pozwalający, zaprzeczający, bezradny. Wyróżnione modele, typy są ściśle związane ze stylami wychowawczymi rodziców. Przeprowadzone współcześnie badania dotyczące podejścia rodziny do spraw seksualności swojego dziecka $\mathrm{z}$ niepełnosprawnością intelektualną ${ }^{11}$

${ }^{9}$ M.R. Brassard, R. Germain, S.N. Hart, Psychological maltreatment of children and youth. Pergamon Press, New York 1987.

${ }^{10}$ M. Beisert, Kazirodztwo. Rodzice w roli sprawców, Wydwanictwo Naukowe Scholar, Warszawa 2004.

11 I. Obuchowska, Drogi dorastania, WSiP, Warszaw 1996; I. Fornalik Miłość, seks i prokreacja jako wartość w dorostym życiu osób z głębsza niepetnosprawnościa intelektualna, [w:] O seksualności osób niepetnosprawnych, red. A. Ostrowska, IRSS, Warszawa 2007; Z. Izdebski, op. cit.; R. Kijak, Seksualność człowieka z niepetnosprawnościa intelektualna a rodzina, PZWL, Warszawa 2014; M. Kościelska, Niechciana seksualność: o ludzkich potrzebach osób niepetnosprawnych intelektualnie, Jacek Senatorski \& Co, Warszawa 2004; M. Kościelska, B. Aouil, Czy i jak wspierać rozwój poczucia tożsamości seksualnej u osób z niepetnosprawnościa intelektualna, [w:] Człowiek niepetnosprawny. Rodzina i praca, red. M. Kościelska, B. Aouil, Wydawnictwo Akademii Bydgoskiej, Bydgoszcz 2004. 
ujawniają, że dominuje model rygorystyczny, jednak najpopularniejszy jest model milczenia12. Charakteryzuje się on brakiem podejmowania dyskusji na temat płci i seksualności, a także izolowaniem od bodźców seksualnych. Obowiązuje bezwzględne tabu w tym obszarze funkcjonowania. M. Beisert ${ }^{13}$ wyróżniła trzy rodzaje tabu stosowane przez rodziców: tabu językowe - polegające na zmowie milczenia na temat seksualności; tabu międzypokoleniowe - związane z brakiem przekazywania informacji pomiędzy pokoleniami; tabu odrębnej płci - w którym obowiązuje tajemnica związana z przynależnością do danej płci. Stosowane przez rodziców tabu nie tylko powoduje ograniczenie i ocenzurowanie informacji na temat seksualności, ale również zmienia ocenę przejawów seksualności (np.: naturalna ciekawość dziecka w tym obszarze odbierana jest jako zachowanie niewłaściwe).

Prezentowane przez rodziców postawy, jak wskazują badania14, nie są związane jedynie z brakiem lub niepełną akceptacją seksualności swoich dzieci z niepełnosprawnością intelektualną, ale także z obawą o ich przyszłość, dorosłość. Wygodniej jest blokować przejawy seksualności dzieci z niepełnosprawnością intelektualną niż przygotować je do odegrania ról społecznych adekwatnych do wieku i możliwości psychofizycznych. Lęk przed podjęciem edukacji seksualnej, będący również następstwem braku dostatecznej wiedzy na temat wsparcia rozwoju psychoseksualnego osób z niepełnosprawnością intelektualną, pogłębia fakt, że rodzice dzieci z niepełnosprawnością intelektualną najczęściej pozostają sami z emocjonalnymi i społecznymi problemami wynikającymi z rozwoju psychoseksualnego swoich dzieci, podlegając jedynie ocenie

12 R. Kijak, op. cit., s. 47.

${ }^{13}$ M. Beisert, Seks twojego dziecka, K. Domke, Poznań 1991, s. 22-25.

14 A. Giryński, Edukacja seksualna osób niepetnosprawnych intelektualnie w świetle opinii rodziców i nauczycieli, [w:] Seksualność osób z niepetnosprawnościa intelektualna uwolnienie od schematów i uprzedzeń, red. J. Głodkowska, A. Giryński, Wydawnictwo Naukowe APS, Warszawa 2005, s. 61-69; M. Kościelska, Być kobieta, być mężczyzna co znaczy w odniesieniu do osób niepetnosprawnych intelektualnie, [w:] O seksualności osób niepetnosprawnych, red. A. Ostrowska, IRSS, Warszawa 2007, s. 35-47 
społeczeństwa15. Pozostawieni sami sobie odczuwają wiele wątpliwości i niepokojów czego wyrazem są obawy głównie przed:

1) ciążą,

2) wykorzystaniem emocjonalnym czy seksualnym,

3) tym, czy wybrany partner będzie odpowiedni - wynikającą z braku faktycznej akceptacji poziomu funkcjonowania swojego dziecka, przez co braku zgody na niepełnosprawnego partnera,

4) niepowodzeniem i frustracją wynikających $z$ niepowodzeń uczuciowych,

5) utratą kontroli nad jedną ze sfer życia dziecka,

6) przyzwoleniem na jakiekolwiek zachowania seksualnego,

7) obsesją seksualną czy rozwiązłością ${ }^{16}$.

Trudno wymagać od rodziców przeżywających takiego rodzaju lęki, nieposiadających całościowej wiedzy o rozwoju psychoseksualnym osób z niepełnosprawnością intelektualną, żeby efektywnie podejmowali edukację seksualną swoich dzieci. Dlatego też niezwykle istotnym wydawało się zbadanie, na ile i w jaki sposób rodzice przygotowują swoje dzieci do funkcjonowania $\mathrm{w}$ tej sferze życia, a także na ile i jak czują się kompetentni do wspierania dzieci w ich rozwoju psychoseksualnym oraz od kogo oczekują pomocy.

\section{Badania własne}

W związku z toczącymi się dyskusjami na temat znaczenia do$\mathrm{mu}$ rodzinnego $\mathrm{w}$ kwestii wychowania seksualnego, przeprowadzono badanie mające na celu zbadanie opinii rodziców dzieci z lekką niepełnosprawnością intelektualną na temat edukacji seksualnej realizowanej $w$ domach rodzinnych. Ważnym wydawało się

${ }^{15}$ Z. Izdebski, op. cit., s. 30-36.

${ }^{16}$ E.A. Przebinda, K. Smakosz, Być kobieta być mężczyzna - dorastanie dzieci głębiej upośledzonych umystowo, [w:] Przewodnik dla nauczycieli uczniów upośledzonych umystowo w stopniu znacznym i umiarkowanym, red. M. Piszczek, CMPPP, Warszawa 2002, s. 42-48. 
zweryfikowanie kto, zdaniem rodziców, powinien prowadzić z dziećmi rozmowy na ten temat, a także jak to powinno być realizowane: w jakim wieku i zakresie. Dodatkowo przeanalizowano, czy respondenci czują się przygotowani do prowadzenia takich rozmów, czy korzystają z jakichś źródeł, by pogłębić swoją wiedzę $\mathrm{w}$ tym zakresie oraz czy sami na te tematy rozmawiają.

W przeprowadzonych badaniach uczestniczyło 30 rodziców dzieci w wieku gimnazjalnym z lekką niepełnosprawnością intelektualną z województwa wielkopolskiego. Dobór próby badawczej był celowy. Badanie zostało przeprowadzone metodą sondażu diagnostycznego za pomocą kwestionariusza ankiety.

Wyniki badania zostały przedstawione poniżej.

Na początku zapytano rodziców, czy, ich zdaniem, posiadają wystarczającą wiedzę na temat rozwoju psychoseksualnego swoich dzieci.

Tabela 1. Opinie rodziców na temat posiadanej przez siebie wiedzy dotyczącej rozwoju psychoseksualnego ich dzieci z lekką niepełnosprawnością intelektualną

\begin{tabular}{|l|c|}
\hline \multicolumn{1}{|c|}{ Opinie na temat posiadanej wiedzy } & Procent odpowiedzi \\
\hline Tak, mam wystarczającą wiedzę & 6,7 \\
\hline Raczej tak & 40 \\
\hline Nie, brak mi zupełnie wiedzy & 26,7 \\
\hline Raczej nie mam wystarczającej wiedzy & 20 \\
\hline Nie wiem & 6,7 \\
\hline
\end{tabular}

Źródło: badania własne

Połowa badanych rodziców uważa, iż posiada (lub raczej posiada) wiedzę na temat rozwoju psychoseksualnego swoich dzieci $\mathrm{z}$ niepełnosprawnością intelektualną. Taki sam procent rodziców przyznaje, iż nie ma takiej wiedzy.

Następnie analizowano, czy rodzice korzystają z jakichś źródeł, żeby tę wiedzę zdobyć. 
Tabela 2. Poszukiwanie wiedzy i informacji przez rodziców dzieci z lekką niepełnosprawnością intelektualną na temat przebiegu rozwoju psychoseksualnego ich dzieci

\begin{tabular}{|c|c|}
\hline Korzystanie ze źródeł & Procent odpowiedzi \\
\hline Tak & $30 \%$ \\
\hline Nie & $63,3 \%$ \\
\hline
\end{tabular}

Źródło: badania własne

Pomimo tego, iż prawie 50 \% rodziców przyznało się do braku wiedzy dotyczącej rozwoju psychoseksualnego swoich dzieci z niepełnosprawnością intelektualną, tylko $1 / 3 \mathrm{z}$ nich poszukuje na ten temat informacji.

Poniżej w tabeli przedstawiono źródła wiedzy rodziców na temat rozwoju psychoseksualnego dzieci z niepełnosprawnością intelektualną.

Tabela 3. Źródła, z których korzystają rodzice dzieci z lekką niepełnosprawnością intelektualną aby zdobyć wiedzę na temat przebiegu rozwoju seksualnego ich dzieci

\begin{tabular}{|l|c|}
\hline \multicolumn{1}{|c|}{ Źródła } & Procent odpowiedzi \\
\hline Internet & 30 \\
\hline Książki & 16,7 \\
\hline Artykuły w gazetach & 10 \\
\hline Programy tv, radiowe & 23,3 \\
\hline Uczestniczenie w szkoleniach & 0 \\
\hline Rozmowy z innymi rodzicami & 13,7 \\
\hline
\end{tabular}

Źródło: badania własne

Rodzice najczęściej, jak wynika z tabeli, poszukując wiedzy i informacji na temat rozwoju seksualnego swoich dzieci, korzystaja $\mathrm{z}$ internetu ( $1 / 3$ badanych), tv i radia $(23,3 \%)$. 
Kolejnym zagadnieniem było zweryfikowanie, kto zdaniem rodziców powinien rozmawiać z dziećmi na tematy płciowości, seksualności. Wyniki zamieszczono w tabeli nr 4 .

Tabela 4. Osoby, które zdaniem rodziców, powinny rozmawiać z dziećmi i młodzieżą z lekką niepełnosprawnością intelektualną na temat płciowości, seksualności

\begin{tabular}{|l|c|}
\hline \multicolumn{1}{|c|}{ Osoby } & Procent odpowiedzi \\
\hline Tylko matka & $10 \%$ \\
\hline Tylko ojciec & 0 \\
\hline Oboje rodzice & $33 \%$ \\
\hline Rodzice i nauczyciele & $80 \%$ \\
\hline Rówieśnicy & 0 \\
\hline Osoby profesjonalnie do tego przygotowane & $56,7 \%$ \\
\hline Ksiądz & 0 \\
\hline
\end{tabular}

Źródło: badania własne

Największa grupa rodziców przyznała, że na tematy związane z płciowością i seksualnością powinni rozmawiać z dziećmi rodzice i nauczyciele oraz osoby profesjonalnie do tego przygotowane.

Kolejne pytania dotyczyły częstotliwości prowadzenia przez rodziców rozmów na ten temat oraz poczucia przygotowania/nieprzygotowania w tym zakresie.

Tabela 5. Częstotliwość prowadzonych przez rodziców rozmów z dziećmi z lekką niepełnosprawnością intelektualną na tematy związane z płciowością, seksualnością

\begin{tabular}{|l|c|}
\hline \multicolumn{1}{|c|}{ Częstotliwość prowadzonych rozmów } & Procent odpowiedzi \\
\hline Nigdy nie rozmawiałam(-em) & 6,7 \\
\hline Raz & 6,7 \\
\hline Kilka razy rozmawiałam(-em) & 60 \\
\hline Często rozmawiam & 16,7 \\
\hline
\end{tabular}

Źródło: badania własne 
Największa grupa rodziców przyznała, że kilka razy rozmawiali z dziećmi na tematy związane z płciowością, seksualnością. 16,7\% deklarowało, że często rozmawia.

Poniżej $\mathrm{w}$ tabeli przedstawiono poziom poczucia przygotowania rodziców do podjęcia rozmów ze swoimi dziećmi na temat rozwoju psychoseksualnego.

Tabela 6. Poczucie przygotowania rodziców do prowadzenia rozmów o seksualności ze swoimi dziećmi

\begin{tabular}{|l|c|}
\hline \multicolumn{1}{|c|}{$\begin{array}{c}\text { Poczucie przygotowania rodziców } \\
\text { do prowadzenia rozmów o seksualności }\end{array}$} & $\begin{array}{c}\text { Procent } \\
\text { odpowiedzi }\end{array}$ \\
\hline Tak, jestem wystarczająco przygotowana(-y) & 16,7 \\
\hline Raczej jestem wystarczająco przygotowana(-y) & 33,3 \\
\hline Nie jestem przygotowany/jestem zupełnie nieprzygotowana(-y) & 13,3 \\
\hline Raczej nie jestem wystarczająco przygotowana(-y) & 33,3 \\
\hline Nie wiem & 3,3 \\
\hline
\end{tabular}

Źródło: badania własne

Otrzymane wyniki wskazują, iż procent rodziców, którzy uznali, iż są wystarczająco przygotowani do prowadzenia ze swoimi dziećmi rozmów na tematy związane z płciowością, seksualnością, jest zbliżony do tych, którzy zaznaczyli, iż są zupełnie nieprzygotowani do tego $(16,7 \%$ do 13,3 \%). Procent rodziców raczej przygotowanych jest równy z procentem tych, którzy zaznaczyli, iż są raczej nieprzygotowani (33,3\%).

Analizie poddano również jakie rodzice podają powody niewystarczającego przygotowania do prowadzenia rozmów na tematy związane z płciowością, seksualnością ze swoimi dziećmi (wyniki w tabeli nr 7).

Rodzice czuli się nieprzygotowani, ponieważ najczęściej nie wiedzieli, jakie tematy mogą poruszyć i jak na te tematy rozmawiać. Jako powody podawali również brak wiedzy i książek poruszających te kwestie. 
Tabela 7. Powody niewystarczającego przygotowania rodziców do prowadzenia rozmów na tematy związane z płciowością, seksualnością ze swoimi dziećmi

\begin{tabular}{|l|c|}
\hline \multicolumn{1}{|c|}{ Powody } & Procent odpowiedzi \\
\hline Nie mam wystarczającej wiedzy & 16,7 \\
\hline Nie wiem jakie tematy mogę poruszyć & 33,3 \\
\hline Nie mam książek, podręczników & 13,3 \\
\hline Nie wiem, jak na te tematy się rozmawia & 33,3 \\
\hline Wstydzę się na te tematy rozmawiać & 3,3 \\
\hline Ze mną nikt na ten temat nie rozmawiał, gdy byłem dzieckiem & 20 \\
\hline Uważam, ze takie rozmowy są niepotrzebne & 3,3 \\
\hline
\end{tabular}

Źródło: badania własne

Interesujące było zbadanie, w jakim wieku, zdaniem rodziców, można rozmawiać $\mathrm{z}$ dziećmi $\mathrm{z}$ niepełnosprawnością intelektualną na poszczególne tematy związane $\mathrm{z}$ płciowością, seksualnością (wyniki w tabeli nr 8).

Tabela 8. Wiek, w którym zdaniem rodziców można poruszać z dzieckiem z niepełnosprawnością intelektualną tematy związane z płciowością, seksualnością

\begin{tabular}{|l|c|}
\hline \multicolumn{1}{|c|}{ Tematy } & Wiek dziecka (lata) \\
\hline Miłość & 12,1 \\
\hline Higiena & 6,9 \\
\hline Związek & 12,7 \\
\hline Podobieństwa i różnice między kobietami i mężczyznami & 9,1 \\
\hline Ciąża, rozmnażanie & 13,9 \\
\hline Zmiany fizyczne związane z okresem dojrzewania & 11,5 \\
\hline Nazwy narządów płciowych & 9,3 \\
\hline Przemoc seksualna & 14,2 \\
\hline Pierwsze kontakty seksualne & 14,7 \\
\hline Antykoncepcja & 14,8 \\
\hline Choroby przenoszone drogą płciową & 15,1 \\
\hline Orientacja seksualna & 14,9 \\
\hline Masturbacja & 13,1 \\
\hline
\end{tabular}

Źródło: badania własne 
Najwcześniej, zdaniem rodziców, można rozmawiać z dziećmi z lekką niepełnosprawnością intelektualną na tematy dotyczące higieny (6,9 lat) podobieństwa i różnic między kobietami i mężczyznami (średni wiek podawany przez rodziców - 9,1 lat) oraz nazw narządów płciowych (9,3 lata). Następnie w wieku 11,5 lat można poruszać kwestie zmian fizycznych związanych z okresem dojrzewania oraz średnio pół roku później tematy dotyczące miłości. $\mathrm{W}$ wieku ponad 12 lat można rozmawiać $\mathrm{z}$ dzieckiem na temat związku, a średnio w wieku 13 lat na temat masturbacji oraz ciąży i rozmnażania (13,9 lat).

Analizowano również jakie tematy są poruszane przez rodziców dzieci z lekką niepełnosprawnością intelektualną w zakresie płciowości, seksualności.

Największa liczba rodziców rozmawiała ze swoimi dziećmi na temat higieny $(96,7 \%)$, podobieństw i różnic pomiędzy kobietami

Tabela 9. Tematy poruszane przez rodziców dzieci z lekką niepełnosprawnością intelektualną dotyczące płciowości, seksualności

\begin{tabular}{|l|l|}
\hline \multicolumn{1}{|c|}{ Tematy } & Procent odpowiedzi \\
\hline Miłość & 63,3 \\
\hline Higiena & 96,7 \\
\hline Związek & 26,7 \\
\hline Podobieństwa i różnice między kobietami i mężczyznami & 93,3 \\
\hline Ciąża, rozmnażanie & 43,3 \\
\hline Zmiany fizyczne związane z okresem dojrzewania & 40 \\
\hline Nazwy narządów płciowych & 86,7 \\
\hline Przemoc seksualna & 23,3 \\
\hline Pierwsze kontakty seksualne & 30 \\
\hline Antykoncepcja & 20 \\
\hline Choroby przenoszone drogą płciową & 10 \\
\hline Orientacja seksualna & 23,3 \\
\hline Masturbacja & 13,3 \\
\hline
\end{tabular}

Źródło: badania własne 
i mężczyznami $(93,3 \%)$, nazw narządów płciowych $(86,7 \%)$. Ponad połowa badanych poruszała temat miłości $(63,3 \%)$; prawie połowa ciąży i rozmnażania $(43,3 \%)$ i nieco mniejsza liczba badanych wskazywała na kwestie związane ze zmianami fizycznymi okresu dojrzewania.

\section{Podsumowanie}

Uzyskane wyniki badań wskazują, że połowa rodziców dzieci z lekką niepełnosprawnością intelektualną ma problemy z prowadzeniem rozmów na temat rozwoju psychoseksualnego swoich dzieci. Te problemy wynikają głównie z braku wiedzy kiedy i jakie informacje powinno się udostępnić. Takie rozbieżności mogą wynikać z postrzegania swoich dzieci jako młodszych (wieczne dzieci), których te tematy jeszcze nie dotyczą. Warto również zauważyć, że pomimo poczucia przez rodziców, że to właśnie oni powinni przekazywać tę wiedzę, czują się oni w tym zakresie nieprzygotowani. $\mathrm{Z}$ jednej strony zauważają oni brak własnych kompetencji $\mathrm{w}$ tym aspekcie, $\mathrm{z}$ drugiej strony nie wykazują $\mathrm{w}$ tym obszarze aktywności prowadzącej do zamiany. Tylko 30\% rodziców deklaruje, że poszukuje wiedzy na ten temat i jak pokazują uzyskane wyniki badań, głównie w Internecie.

Podsumowując, na podstawie analizy wyników zauważono, iż:

1. Połowa rodziców przyznaje, że nie posiada wiedzy na temat rozwoju psychoseksualnego swoich dzieci z niepełnosprawnością intelektualną.

2. Tylko $1 / 3$ poszukuje informacji na ten temat. Rodzice najczęściej korzystają z Internetu i tv oraz radia.

3. Wskazują, iż rozmowy na temat seksualności powinny prowadzić rodzice i nauczyciele oraz osoby profesjonalnie do tego przygotowane.

4. Pomimo iż rodzice podawali samych siebie jako potencjalnych „edukatorów seksualnych”, blisko połowa z nich $(46,6 \%)$ czuje 
się nieprzygotowana lub raczej nieprzygotowanai do prowadzenia tego typu rozmów.

5. Jako najczęstsze trudności, które napotykają przy prowadzeniu takich rozmów, wskazywali brak wiedzy dotyczącej tego, jakie tematy mogą poruszyć i jak na te tematy rozmawiać.

6. Pomimo iż rodzice wskazywali, że należy na te tematy rozmawiać, jeśli chodzi o poruszane przez nich kwestie, to tylko $40 \%$ rodziców rozmawia o zmianach związanych $\mathrm{z}$ dojrzewaniem, $13,3 \%$ o masturbacji, $23,3 \%$ porusza tematy dotyczące orientacji seksualnej, 1/3 rozmawia z dziećmi o pierwszych kontaktach seksualnych, $20 \%$ o antykoncepcji. Tylko co dziesiąty rodzic omawia temat chorób przenoszonych drogą płciową, a ponad 1/5 rodziców podejmuje problematykę związaną z przemocą seksualną.

\section{Dyskusja wyników}

Z przeprowadzonych badań wynika, iż rodzice dzieci z niepełnosprawnością intelektualną czują się nieprzygotowani w zakresie edukacji seksualnej swoich dzieci. Często popełniają, jak pisze Izabela Fornalik ${ }^{17}$ : „błąd opóźniania“, czyli przekazują treści zbyt późno, już po wystąpieniu jakichś doświadczeń czy przejawów związanych $\mathrm{z}$ fazą rozwojową. Jest to tym bardziej niepokojące, że $\mathrm{w}$ przypadku dzieci z lekką niepełnosprawnością intelektualną edukacja powinna tym bardziej wyprzedzać pojawienie się nowych doświadczeń, by miały one czas na przećwiczenie, utrwalenie i uogólnienie sposobów radzenia sobie w nowej sytuacji. Biorąc pod uwagę fakt, iż niniejsze badanie dotyczyło rodziców dzieci w wieku gimnazjalnym, niepokój mogą budzić wyniki odnoszące się do tematów poruszanych przez rodziców (tabela 9: 40\% rodziców deklarowało rozmowę na temat zmian fizycznych związanych

${ }^{17}$ I. Fornalik, Edukacja seksualna osób z niepetnosprawnościa intelektualną. W poszukiwaniu właściwego modelu, [w:] Przemiany seksualności w społeczeństwie wspótczesnym. op. cit, s. 158-163. 
z okresem dojrzewania, $13,3 \%$ na temat masturbacji, $10 \%$ na temat chorób przenoszonych droga płciową).

Taka sytuacja nie sprzyja rozwojowi psychoseksualnemu dzieci i młodzieży z lekką niepełnosprawnością intelektualną, ponieważ może powodować, iż dzieci nie będą rozumiały przejawów swojej płciowości i seksualności, a tym samym mogą przeżywać w związku z tym szereg trudnych emocji: wstyd, lęk, poczucie winy.

Niepokój budzi również niewielki procent rodziców poruszających z dziećmi temat masturbacji (13,3\%). Jedną z ważnych kwestii $\mathrm{w}$ aspekcie wspierania rozwoju psychoseksualnego swoich dzieci jest przygotowywanie ich do czekającej fazy rozwojowej, a więc dostarczenie wiedzy i informacji na temat mogących się pojawić przejawów i zachowań i odpowiednie reagowanie dorosłych na te zdarzenia. Jeśli tylko tak mały odsetek rodziców rozmawia na temat masturbacji, to $\mathrm{w}$ tym przypadku nie możemy mówić ani o przygotowaniu, ani o pomocy młodzieży (nauce akceptowanych form rozładowania napięcia, ochronie swoich granic, budowaniu intymności).

Warto pamiętać również o tym, iż w przypadku dzieci z niepełnosprawnością intelektualną brak wiedzy w tym zakresie może być trudniej uzupełniany, a zatem jeśli rodzice nie przekażą potrzebnych informacji, dostęp do innych źródeł (Internetu, ksiązek) może być utrudniony ${ }^{18}$. Należy również zwrócić uwagę na fakt, że osoby z niepełnosprawnością intelektualną najczęściej wyrażają swoją seksualność poprzez masturbację i petting ${ }^{19}$, dlatego odpowiednie przygotowanie do tej formy aktywności ma szczególne znaczenie dla jakości przyszłego życia.

Rodzice, m.in. z racji braku przygotowania do prowadzenia edukacji seksualnej swoich dzieci, oczekują przejęcia inicjatywy w tym obszarze przez nauczycieli, co jest zgodne $\mathrm{z}$ przeprowa-

18 Ibidem, s. 158-163.

19 A. Szollos, M.P. McCabe, The sexuality of people with mild intellectual disabilities: Perceptions of clients and caregivers, "Journal of Intellectual and Developmental Disability" 1995, 20(3), s. 205-222. 
dzonymi badaniami m.in.: Andrzeja Girńskiego ${ }^{20}$, Patrycja Jurkiewicz ${ }^{21}$.

Należy jednak pamiętać, iż rola rodziców, w szczególności prezentujących pozytywne style wychowawcze $\mathrm{w}$ kształtowaniu się dobrych doświadczeń seksualnych wspomagających ich proces uspołecznienia, jest bardzo istotna ${ }^{22}$

Jak pisze I. Fornalik ${ }^{23}$, treści w zakresie edukacji seksualnej dzieci z niepełnosprawnością intelektualną nie powinny w żaden znaczący sposób odbiegać od problematyki poruszanej przez dzieci $\mathrm{w}$ normie intelektualnej. Dzieci w okresie gimnazjalnym znajduja się $\mathrm{w}$ fazie dojrzewania, a więc już znacznie wcześniej powinny być im przekazane informacje na ten temat ( $\mathrm{w}$ tym również $\mathrm{w}$ aspekcie orientacji seksualnej), a kolejne treści powinny się odnosić do mogących się pojawić w przyszłości wydarzeń i doświadczeń.

Dbanie o bezpieczeństwo swoich dzieci wiąże się z przekazywaniem wiedzy, uczeniem prozdrowotnych zachowań, ochroną swoich praw. Niestety tylko mały odsetek rodziców deklaruje podejmowanie rozmów na tematy wiążące się z zagrożeniami: chorobami przenoszonymi drogą płciową czy przemocą seksualną.

Fornalik ${ }^{24}$ podaje, iż taka postawa unikająca wobec seksualności swoich dzieci może wynikać z:

- braku wiedzy dotyczącej tego na ile niepełnosprawność intelektualna wpływa na rozwój seksualny,

- koncentracji na niepełnosprawności i formach usprawniania i rehabilitacji (kwestie seksualności stają się drugorzędne),

- chęci, by dziecko pozostało aseksualne,

20 A. Giryński, op. cit., s. 68.

${ }^{21}$ P. Jurkiewicz, Rodzice wobec seksualności osób z niepetnosprawnością intelektualna, [w:] Seksualność- Niepetnosprawność - Rzeczywistość wspótczesne konteksty badawcze w problematyce seksualności człowieka z niepetnosprawnościa, red. R. Kijak, IRSS, Warszawa 2013, s. 247.

${ }^{22}$ Co potwierdzają badania m.in.: E. Pisuli (1998), M. Kościelskiej (1998), S. Kowalika (2007).

${ }^{23}$ I. Fornalik, op. cit.

24 Ibidem, s. 158-163. 
- swoich osobistych problemów z partnerem, seksualnością, związkiem (brak czasu dla siebie, konflikty, przemęczenie, które wpływają na jakość związku),

- poczucie osamotnienia ze strony placówek (brak inicjatyw ze strony specjalistów).

Z powyższego wynika, iż istnieje uzasadniona potrzeba wspierania rodziców w zakresie wiedzy, informacji, a także kompetencji i umiejętności w kontekście edukacji i wychowania seksualnego swoich dzieci. Brak edukacji seksualnej prowadzonej przez rodziców osób z niepełnosprawnością intelektualną może prowadzić do: frustracji i niepokojów związanych z brakiem zrozumienia zmian zachodzących w organizmie w okresie dojrzewania, przejawiania zachowań seksualnych w miejscach publicznych, angażowania się w nieprawidłowe czy ryzykowne relacje seksualne, pojawieniem się niechcianych doświadczeń seksualnych (np. chorób przenoszonych drogą płciową, ciąży) $)^{25}$.

W celu wsparcia rodziców dzieci z niepełnosprawnością intelektualną powinno się podjąć szereg profesjonalnych oddziaływań. Oddziaływań, które biedą miały na celu przełamanie społecznego tabu i zwrócenie uwagi na potrzebę edukacji rodziców. Kluczowe dla uzyskania pozytywnych rezultatów tych działań jest przekazanie rodzicom wiedzy dotyczącej roli edukacji seksualnej dla rozwoju i przyszłej jakości życia ich niepełnosprawnych dzieci jak najwcześniej, gdy ich dzieci znajdują się jeszcze w fazie wczesnego dzieciństwa. Inaczej rodzice pozostawieni $z$ emocjonalnymi i społecznymi problemami wynikającymi z rozwoju psychoseksualnego swoich podopiecznych, podlegając przy tym także ocenie społeczeństwa, mogą sobie nie poradzić ze zmianą w podejściu do edukacji seksualnej. A tylko taka zmiana może zaowocować podniesieniem poziomu funkcjonowania psychospołecznego osób z lekką niepełnosprawnością intelektualną.

${ }^{25}$ G. Fairbairn, D. Rowley, Etyczne aspekty seksualności osób z niepetnosprawnościq intelektualną, [w:] Seksualność osób z niepetnosprawnościa intelektualna - uwolnienie od schematów i uprzedzeń, red. J. Głodkowska, A. Giryński, Wydawnictwo Naukowe APS, Warszawa 2005. 


\section{Bibliografia}

Badanie CBOS i Kampanii Świadomego Rodzicielstwa, marzec 2010, Badanie CBOS, marzec 2010, wywiady pogłębione z 30 „młodocianymi dziadkami”, tj. osoba$\mathrm{mi}$, które zostały babcią/dziadkiem zanim ich syn/córka ukończyły 18 lat; 2 Badanie CBOS, marzec 2010, wywiady pogłębione z 30 „młodocianymi dziadkami", tj. osobami, które zostały babcią/dziadkiem zanim ich syn/córka ukończyły 18 lat; 3 Badanie CBOS, kwiecień 2008, reprezentatywna próba ogólnopolska 495 osób w wieku 13-21 lat; 1 Badanie CBOS, kwiecień 2008, wywiady pogłębione z 30 młodocianymi matkami z różnych regionów Polski, 14 kobiet urodziło $\mathrm{w}$ ciągu ostatnich 12 miesięcy, 6 nie później niż 5 lat temu, 5 ponad 5 lat temu i 10 ponad 10 lat temu przeprowadzone na zlecenie organizatorów Kampanii na Rzecz Świadomego Rodzicielstwa "Kiedy 1+1=3”, 2 Badanie CBOS, marzec/kwiecień 2009, wywiady pogłębione z 30 młodocianymi ojcami $\mathrm{z}$ różnych regionów Polski, 7 mężczyzn zostało ojcami w ciągu ostatnich 12 miesięcy, 5 mężczyzn nie później niż 5 lat temu, 5 ponad 5 lat temu i 13 ponad 10 lat temu; http:/ / www.newsweek. pl/polska/edukacja-seksualna-w-polsce-czyli-1-1-3,59080,1,1.html, www.swiadomerodzicielstwo.com. [dostęp: 31.03.2016].

Beisert M., Kazirodztwo. Rodzice w roli sprawców, Wydawnictwo Naukowe Scholar, Warszawa 2004.

Beisert M., Seks twojego dziecka, K. Domke, Poznań 1991.

Boczar K., Młodzież upośledzona umystowo w rodzinie i środowisku pracy, IWZZ, Warszawa 1982.

Borzyszkowska H., Dziecko upośledzone w rodzinie, [w:] Pedagogika rewalidacyjna, PWN, red. A. Hulek, Warszawa 1998.

Brassard M. R., Germain., Hart S. N., Psychological maltreatment of children and youth. Pergamon Press, New York 1987.

Fairbairn G., Rowley D., Etyczne aspekty seksualności osób z niepetnosprawnościa intelektualna, [w:] Seksualność osób z niepetnosprawnościa intelektualna - uwolnienie od schematów i uprzedzeń, red. J. Głodkowska, A. Giryński, Wydawnictwo Naukowe APS, Warszawa 2005.

Fornalik I., Edukacja seksualna osób z niepetnosprawnością intelektualną. W poszukiwaniu właściwego modelu, [w:] Przemiany seksualności w społeczeństwie wspótczesnym. Teoria i rzeczywistość, red. Z. Lew-Starowicz, K. Waszyńska, Wydawnictwo Naukowe UAM, Poznań 2012.

Fornalik I., Mitość, seks i prokreacja jako wartość w dorostym życiu osób z głębsza niepetnosprawnościa intelektualna, [w:] O seksualności osób niepetnosprawnych, red. A. Ostrowska, IRSS, Warszawa 2007.

Giryński A., Edukacja seksualna osób niepetnosprawnych intelektualnie w świetle opinii rodziców i nauczycieli, [w:] Seksualność osób z niepetnosprawnościa intelektualna - 
uwolnienie od schematów i uprzedzeń, red. J. Głodkowska, A. Giryński, Wydawnictwo Naukowe APS, Warszawa 2005

Haffner D., Jak rozmawiać z dziećmi o sprawach intymnych?, Grupa Wydawnicza Bertelsmann Media, Warszawa 2002.

Izdebski Z., Rodzice dziecka niepetnosprawnego wobec jego seksualności, [w:] O seksualności osób niepetnosprawnych, red. A. Ostrowska, IRSS, Warszawa 2007.

Jurkiewicz P., Rodzice wobec seksualności osób z niepełnosprawnościa intelektualna, [w:] Seksualność- Niepetnosprawność- Rzeczywistość wspótczesne konteksty badawcze w problematyce seksualności cztowieka z niepetnosprawnościa, red. R. Kijak, IRSS, Warszawa 2013.

Kijak R., Seksualność czlowieka z niepetnosprawnościa intelektualna a rodzina, PZWL, Warszawa 2014.

Kościelska M., Aouil B., Czy i jak wspierać rozwój poczucia tożsamości seksualnej u osób z niepetnosprawnościa intelektualna, [w:] Człowiek niepetnosprawny. Rodzina i praca, red. M. Kościelska, B. Aouil, Wydawnictwo Akademii Bydgoskiej, Bydgoszcz 2004.

Kościelska M., Być kobieta być mężczyzna - co znaczy w odniesieniu do osób niepetnosprawnych intelektualnie, [w:] O seksualności osób niepetnosprawnych, red. A. Ostrowska, IRSS, Warszawa 2007.

Kościelska M., Niechciana seksualność: o ludzkich potrzebach osób niepetnosprawnych intelektualnie, Jacek Senatorski \& Co, Warszawa 2004.

Kościelska M., Trudne macierzyństwo, WSiP, Warszawa 1998.

Kowalik S., Psychologia rehabilitacji, Wydawnictwo AiP, Warszawa 2007.

Kozakiewicz., U podstaw wychowania seksualnego, PZWL, Warszawa 1969.

Laush-Żuk J., Pedagogika osób z umiarkowanym, znacznym i głębokim upośledzeniem umystowym, [w:] Pedagogika specjalna, red. W. Dykcik, Wydawnictwo Naukowe UAM, Poznań 2001.

Minczakiewicz E., Dziecko niepetnosprawne w rodzinie i w szkole, Oficyna Wydawnicza Impuls, Kraków 2002.

Obuchowska I., Drogi dorastania, WSiP, Warszaw 1996

Pedagogika specjalna, red. W. Dykcik, Wydawnictwo Naukowe UAM, Poznań 2006.

Pighin, G., Skąd się bierze dziecko w brzuchu mamy?, Oficyna Wydawnicza GMP, Poznań, 1995.

Pisula E., Psychologiczne problemy rodziców dzieci z zaburzeniami w rozwoju, Wydawnictwo UW, Warszawa 1998.

Przebinda, K. Smakosz E.A., Być kobieta być mężczyznq - dorastanie dzieci głęiej upośledzonych umysłowo, [w:] Przewodnik dla nauczycieli uczniów upośledzonych umystowo w stopniu znacznym i umiarkowanym, red. M. Piszczek, CMPPP, Warszawa 2002.

Saint-Pierre F., Viau, M.F., Seksualność dziecka, Bauer - Weltbild Mediao, Warszawa 2006 
Stelter Ż., Dorastanie osób z niepetnosprawnościa intelektualną, Scholar, Warszawa 2009. Szollos A., McCabe M.P., The sexuality of people with mild intellectual disabilities: Perceptions of clients and caregivers, "Journal of Intellectual and Developmental Disability" 1995, 20(3) 205-222.

Twardowski A., Sytuacja rodzin dzieci niepetnosprawnych, [w:] Dziecko niepetnosprawne w rodzinie, red. I. Obuchowska, WSiP, Warszawa 2005.

Waszyńska K., Przejawy seksualności dziecka w wieku przedszkolnym - kontekst edukacyjny, [w:] Przemiany seksualności w społeczeństwie współczesnym. Teoria i rzeczywistość, red. Z. Lew-Starowicz, K. Waszyńska, Wydawnictwo Naukowe UAM, Poznań, 2012. 